\title{
Projekty turystyczne współfinansowane ze środków Unii Europejskiej w województwie małopolskim
}

\section{Tourism Projects Co-Financed by the European Union in the Małopolskie Voivodeship (Poland)}

\begin{abstract}
Streszczenie: Turystyka stanowi jeden z kluczowych sektorów europejskiej gospodarki, a inicjatywy turystyczne finansowane przez Unię Europejską (UE) promują przedsiębiorczość i rozwój regionów. Autorka niniejszego artykułu podkreśla, że edukacja w tej dziedzinie jest bardzo ważna, ponieważ może kreować postawy przedsiębiorcze i podnosić jakość kapitału ludzkiego. Celem artykułu jest przedstawienie podstaw prawnych i kompetencji instytucji Unii Europejskiej w dziedzinie turystyki oraz funduszów europejskich finansujących projekty turystyczne, a także analiza projektów turystycznych finansowanych ze środków unijnych w województwie małopolskim na tle Polski. Artykuł jest podzielony na trzy części. Zakres czasowy badań obejmuje okres programowania 2007-2013. W świetle przeprowadzonych rozważań można zauważyć, że sektor turystyczny od dawna nie jest priorytetowy w polityce UE i wciąż brakuje instrumentów finansowych całkowicie zorientowanych na projekty turystyczne. W omawianym czasie w województwie małopolskim najważniejszą rolę odgrywały projekty z kategorii rozwoju biznesu, nauki i edukacji oraz pracy i integracji społecznej. Projekty turystyczne miały znacznie mniejsze znaczenie w ogólnej liczbie projektów wspieranych z unijnych funduszy. Ważny jest jednak fakt, że wiele projektów turystycznych miało charakter międzynarodowy i wspierało regionalną przedsiębiorczość.
\end{abstract}

\begin{abstract}
Tourism is one of the basic sectors of the European economy. Tourism initiatives funded by the European Union promote entrepreneurship and development of regions. The author emphasizes the role of education in this field as it can create entrepreneurial attitudes and improve the quality of human capital. The aim of the article was to present the legal basis and competences of EU institutions in the field of tourism and the European funds financing tourism projects. The author presents tourism projects financed from the EU funds in Małopolskie Voivodeship in relation to Poland. Therefore, the article is divided into three parts. The study refers to the programming period of 2007-2013. In the light of the conducted considerations, we can see that tourism sector has not been a preferential one for a long time in the EU policy. There is still a lack of financial instruments entirely oriented on tourism projects. The most important role in the Małopolskie Voivodeship played projects in the category of business development, science and education, as well as work and social integration. Tourism projects played a smaller role in the total number of projects supported by EU funds. However, it is important that many tourism projects are international and support regional entrepreneurship.
\end{abstract}


Słowa kluczowe: fundusze europejskie; projekty Unii Europejskiej; turystyka; województwo małopolskie

Keywords: European funds; European Union projects; Małopolskie Voivodeship; tourism

Otrzymano: 7 stycznia 2020

Received: 7 January 2020

Zaakceptowano: 14 września 2020

Accepted: 14 September 2020

\section{Sugerowana cytacja/Suggested citation:}

Borowiec-Gabryś, M. (2020). Projekty turystyczne współfinansowane ze środków Unii Europejskiej w województwie małopolskim. Przedsiębiorczość - Edukacja [Entrepreneurship - Education], 16(2), 261-273. doi: $10.24917 / 20833296.162 .21$

\section{Wstęp}

Kreowanie innowacyjnych produktów turystycznych wpływających na zwiększenie jakości życia społeczeństwa, aktywizację gospodarczą i rozwój przedsiębiorczości ma duże znaczenie w podnoszeniu konkurencyjności różnej skali układów przestrzennych: od układów lokalnych i regionalnych po układy krajowe, a nawet międzynarodowe (Borowiec, Dorocki, 2014; Čuka, Dorocki, Rachwał, 2015; Dorocki, 2007; Dorocki, Brzegowy, 2015; Jaroszewska-Brudnicka, 2013; Panasiuk, 2014; Rettinger, 2010; Siwa, 2006; Zdon-Korzeniowska, 2009; Zontek, 2013). Turystyka stanowi jeden z kluczowych sektorów europejskiej gospodarki i postrzegana jest jako czynnik zwiększający spójność terytorialną oraz dynamizujący rozwój regionów. W konsekwencji zwiększa się jej znaczenie w polityce Unii Europejskiej (UE). Szacuje się, że w turystyce UE istnieje $17 \mathrm{mln}$ miejsc pracy, a udział tego sektora w gospodarce wynosi ok. 10\% PKB UE (Przewodnik po funduszach UE..., 2016). W Polsce udział sektora turystycznego w gospodarce od wielu lat utrzymuje się na poziomie 5-6\% PKB, a zatrudnienie znajduje w nim ok. 760 tys. osób, co stanowi 4,7\% ogólnej liczby zatrudnionych. Zgodnie z szacunkami ekspertów, jedno miejsce pracy w sektorze turystyki generuje dodatkowo do 3-4 miejsc pracy w infrastrukturze okołoturystycznej (Program rozwoju turystyki do 2020 roku, 2015).

Turystyka odgrywa dużą rolę w rozwoju społeczno-gospodarczym, przestrzennym i funkcjonalnym wielu europejskich miast, a w Polsce staje się coraz ważniejszą częścią polityki regionalnej. Wzrasta zatem znaczenie edukacji dotyczącej roli turystyki w polityce regionalnej oraz pozyskiwania europejskich środków na finasowanie różnego rodzaju projektów i działań przedsiębiorczych w turystyce. Należy podkreślić, że polski Program rozwoju turystyki do 2020 roku wpisuje się we wszystkie priorytety określone w dokumentach strategicznych na poziomie europejskim, czyli w Strategii Europa 2020 oraz Strategii Unii Europejskiej dla regionu Morza Bałtyckiego. Założenia nowych ram rozwoju turystyki w Polsce do roku 2020 uwzględniają fakt, że w polityce europejskiej wsparcie rozwoju turystyki związane jest ściśle z rozwojem przedsiębiorczości, oraz że coraz bardziej będzie ono związane z procesami rewitalizacji, rozwojem miast i zagospodarowaniem przestrzeni miejskich. Można zatem przyjąć, że stopień wykorzystania funduszy europejskich na projekty turystyczne w poszczególnych województwach jest wyrazem przedsiębiorczości regionalnej. „Turystyka to obszar generowania specjalizacji regionalnych na bazie regionalnych zasobów i infrastruktury, produktów 
regionalnych, sieci kooperacyjnych i innowacyjnych, łańcuchów produktowych i technologicznych" (Program rozwoju turystyki do 2020 roku, 2015: 4).

Jak przyjmuje Z. Zioło, „w strategiach rozwoju społeczno-gospodarczego i kulturowego układów przestrzennych podstawowe znaczenie ma kształtowanie społecznego potencjału przedsiębiorczości” (Zioło, 2015: 9). Wydaje się zatem, że szczególnie istotna jest edukacja młodych ludzi w zakresie różnego rodzaju projektów, inicjatyw czy konkursów współfinansowanych ze środków UE w obszarze turystyki, gdyż może ona wpływać na kształtowanie postaw przedsiębiorczych i efektywne pozyskiwanie funduszy, a także na rozwój zawodowy oraz rozwój pasji turystycznych. Wszystko to ma znaczenie dla jakości kapitału ludzkiego w układach przestrzennych, a w konsekwencji - dla ich społeczno-gospodarczego rozwoju.

W nawiązaniu do powyższych przesłanek w niniejszym artykule zostaną przedstawione podstawy prawne i kompetencje instytucji UE w zakresie sektora turystyki oraz funduszów europejskich finansujących projekty turystyczne. Celem artykułu jest określenie znaczenia turystyki w polityce UE oraz znaczenia projektów finansowanych ze środków UE w województwie małopolskim w latach 2007-2013, a w szczególności - znaczenia projektów turystycznych w tym województwie na tle ogólnej liczby przedsięwzięć wspieranych ze środków unijnych we wspomnianej perspektywie finansowej w Polsce. Wydaje się, że wybitne walory przyrodnicze, historyczne i kulturowe województwa małopolskiego $\mathrm{w}$ powiązaniu z przedsiębiorczością władz samorządowych predestynują je do bycia liderem w zakresie tego typu projektów.

Źródło danych statystycznych użytych w badaniach stanowił głównie serwis internetowy Mapa Dotacji UE (www.mapadotacji.gov.pl), współfinansowany przez UE ze środków Funduszu Spójności w ramach Programu Pomoc Techniczna 2014-2020 Ministerstwa Funduszy i Polityki Regionalnej.

\section{Kompetencje instytucji Unii Europejskiej w zakresie turystyki}

Pierwsze zapisy dotyczące turystyki w UE zostały wprowadzone do Traktatu ustanawiającego Wspólnotę Europejska podpisanego w Maastricht (Zawistowska, Raciniewska, Macierzyńska, 2009). Do tego czasu w traktatach unijnych brakowało postanowień odnoszących się do turystyki. Do art. 3 traktatu z Maastricht wprowadzono zapis, zgodnie z którym, aby osiągnąć cele Wspólnoty, jej działalność obejmuje m.in. „środki w dziedzinach energetyki, obrony cywilnej i turystyki”. Nie upoważniało to jednak do objęcia turystyki wspólną polityką UE, ale było dowodem dostrzeżenia ważnej roli turystyki w realizacji unijnych celów. Kolejne traktaty nie wprowadziły żadnych zmian w tym zakresie, dopiero traktat lizboński znaczenie rozszerzył kompetencje UE, przyznając jej instytucjom uprawnienia do prowadzenia działań w sektorze turystyki (tzw. kompetencje wspomagające). Turystyka nie została jednak zaliczona do obszarów objętych wspólną polityką UE. Zakres kompetencji unijnych instytucji został określony w art. 195 traktatu lizbońskiego, zgodnie z którym UE uzupełnia działania państw członkowskich zwłaszcza przez wspieranie konkurencyjności w tym sektorze. Unia ma zatem kompetencje do prowadzenia działań mających na celu wspieranie, koordynowanie lub uzupełnianie działań państw członkowskich w dziedzinie turystyki. W odniesieniu do sektora turystyki obwiązuje zasada subsydiarności, a zasadnicze znaczenie mają dla niego działania z zakresu m.in. polityki transportowej, ochrony środowiska, polityki regionalnej czy rozwoju obszarów 
wiejskich. Ten intersektorowy charakter turystyki powoduje, że pośrednio lub bezpośrednio odnosi się do niej wiele aktów prawa unijnego.

Zwiększające się zainteresowanie rolą turystyki w tworzeniu miejsc pracy obserwuje się od 21 czerwca 1999 r., kiedy to odbyło się posiedzenie Rady Europejskiej dotyczące turystyki i zatrudnienia (Coito, Klaus, Blazer, 2020). Wyrazem dostrzeżenia zwiększającej się roli turystyki w rozwoju społeczno-gospodarczym jest również utworzenie nowego organu UE - Wydziału Turystyki w Dyrekcji Generalnej ds. Przedsiębiorczości i Przemysłu. Organem opiniodawczo-doradczym Komisji Europejskiej (KE) w sprawach turystyki jest Doradczy Komitet Turystyki.

Komisja Europejska pracuje nad inicjatywami dywersyfikującymi i poprawiającymi oferty produktów i usług turystycznych, zwiększającymi mobilność i umiejętności pracowników (zwłaszcza w zakresie kompetencji informatycznych) oraz wspierającymi przedsiębiorców z branży turystycznej w zarządzaniu ich przedsiębiorstwami. Poza tym współpracuje z państwami spoza UE i organizacjami międzynarodowymi w celu zwiększenia roli turystyki w Europie oraz wdraża rozwiązania komunikacyjne i promocyjne ułatwiające podróżowanie do UE. Od 2001 r. KE opublikowała kilka komunikatów, w których określiła wytyczne dotyczące rozwoju turystyki, oraz przygotowała wirtualne Europejskie Obserwatorium Turystyki - portal, który gromadzi informacje i analizy dotyczące wydajności i trendów w sektorze turystycznym, co ułatwia opracowywanie skuteczniejszych strategii rozwoju tego sektora.

W strukturach Parlamentu Europejskiego (PE) funkcjonuje Komisja Transportu i Turystyki, która przygotowuje projekty opinii i raportów dotyczących turystyki, takie jak projekt Rezolucji Parlamentu Europejskiego w sprawie Europy - najpopularniejszego kierunku turystycznego na świecie - nowych ram politycznych dla europejskiego sektora turystycznego (Dz.Urz. Unii Europejskiej C 355/10, 20.10.2017).

Warto podkreślić, że w ramach rozwoju turystyki UE ustanowiła 2018 r. Europejskim Rokiem Turystyki UE-Chiny, co miało na celu promowanie mniej znanych ośrodków turystycznych, poprawę jakości podróżowania, wspieranie współpracy gospodarczej i zachęcanie do wprowadzania ułatwień wizowych i nowych połączeń lotniczych. Duże znaczenie dla rozwoju turystyki mają również unijne inicjatywy, takie jak: „Eden”, „Calypso”, „Zrównoważona turystyka” czy „NECSTouR”.

Rezolucja PE z dnia 29 października 2015 r. w sprawie nowych wyzwań i koncepcji w zakresie promowania turystyki w Europie: „zdecydowanie zachęca Komisję do tego, by we współpracy z Europejską Komisją Turystyki (ETC), która zrzesza krajowe organizacje turystyczne, w dalszym ciągu promowała Europę jako najpopularniejszy kierunek turystyczny na świecie w ramach wspólnego europejskiego podejścia; apeluje przede wszystkim o wdrożenie długofalowej strategii zainicjowanej przez Komisję i ETC w lutym 2014 r. pod hasłem »Kierunek Europa 2020«, która obejmuje szereg działań marketingowych i promocyjnych, a także działań służących budowaniu wizerunku Europy jako kierunku turystycznego" (Dz.Urz. Unii Europejskiej C 355/74, 20.10.2017).

\section{Fundusze Unii Europejskiej wspierające projekty turystyczne}

Jak zostało wspomniane, turystyka, pomimo dużego znaczenia w gospodarkach poszczególnych państw członkowskich, przez długi czas nie miała priorytetowego znaczenia w polityce wspólnotowej (Sysiak, 2013). Odzwierciedla to również fakt, że nie ma instrumentów 
finansowych w całości zorientowanych na projekty turystyczne. Finansowanie tego typu projektów odbywa się zatem z wykorzystaniem środków z następujących funduszy:

1. Europejski Fundusz na rzecz Inwestycji Strategicznych,

2. Europejski Fundusz Rozwoju Regionalnego,

3. Fundusz Spójności,

4. Europejski Fundusz Społeczny,

5. Europejski Fundusz Rolny na rzecz Rozwoju Obszarów Wiejskich,

6. Europejski Fundusz Morski i Rybacki.

Działania sektora turystycznego, które kwalifikują się do finasowania z Europejskie-

go Funduszu na rzecz Inwestycji Strategicznych (EFiS), mogą dotyczyć:

- infrastruktury podróżniczej,

- efektywności energetycznej hoteli i ośrodków turystycznych,

- rewitalizacji nieużytków do celów rekreacyjnych,

- umów finansowych małych i średnich przedsiębiorstw turystycznych,

- utworzenia „platform inwestycyjnych” poświęconych turystyce.

Szerokie wsparcie dla sektora turystyki oferuje Europejski Fundusz Rozwoju Regionalnego (EFRR). W jego ramach wsparcie można uzyskać w 11 tzw. „celach tematycznych i priorytetach inwestycyjnych", zgodnie z priorytetami w zakresie polityki strategii Europa 2020. Dla sektora turystyki najważniejsze są poniższe cele:

- badania naukowe i innowacje, które mogą wspierać rozwój technologiczny i innowacje w turystyce (cel 1),

- technologie informacyjno-komunikacyjne związane z turystyką (cel 2),

- konkurencyjność małych i średnich przedsiębiorstw turystycznych, szczególnie na obszarach peryferyjnych i słabiej rozwiniętych (cel 3),

- przejście na gospodarkę niskoemisyjną poprzez działania zwiększające efektywność energetyczną oraz korzystanie $\mathrm{z}$ odnawialnych źródeł energii wśród MŚP sektora turystycznego (cel 4),

- ochrona środowiska i efektywne gospodarowanie zasobami, promocja i rozwój zasobów przyrodniczych i kulturalnych turystyki oraz powiązanych z nimi usług; rozwój infrastruktury turystyki kulturalnej oraz działania na rzecz powiązania regionów przybrzeżnych z obszarami położonymi w głębi lądu (cel 6),

- zatrudnienie i wspieranie mobilności pracowników, działania promujące przedsiębiorczość, samozatrudnienie i tworzenie przedsiębiorstw, a także umiędzynarodowienie MŚP i klastrów, rozwój produktów i usług o wysokiej wartości dodanej na rynkach niszowych (cel 8),

- uczenie się przez całe życie poprzez szkolenia zawodowe i różnego rodzaju kursy podnoszące kompetencje pracowników związanych z sektorem turystycznym (cel 10).

Kolejnym wsparciem dla turystyki mogą być środki Funduszu Spójności (FS), który wspiera zwłaszcza inwestycje na rzecz środowiska oraz rozwój transeuropejskich sieci transportowych. Rodzaj działań związanych z turystyką zależy od potrzeb poszczególnych państw członkowskich wskazywanych w ich programach operacyjnych.

Następny fundusz mający znaczenie dla sektora turystyki to Europejski Fundusz Społeczny (EFS), którego głównym celem jest zwiększenie poziomu zatrudnienia i poprawa mobilności, a także podwyższenie poziomu kwalifikacji zawodowych w UE poprzez szkolenia podnoszące kompetencje pracowników sektora turystyki, umożliwiające przekwalifikowanie czy zdobycie szczegółowych uprawnień w różnych dziedzinach turystycznych. 
Europejski Fundusz Rolny na rzecz Rozwoju Obszarów Wiejskich (EFRROW) wspiera z kolei rozwój turystyki wiejskiej i aktywizację mieszkańców obszarów wiejskich. Jak podkreśla Komisja Europejska, istotne znaczenie ma również stymulowanie przez turystykę działań związanych z produkcją żywności, zasobami naturalnymi oraz aspektami terytorialnymi. Środki tego funduszu mogą być wykorzystane na:

- szkolenia i kursy zawodowe, warsztaty, sesje coachingowe, usługi doradcze,

- wsparcie start-upów oraz inwestowanie w działalność pozarolniczą na obszarach wiejskich,

- sporządzanie i aktualizowanie planów rozwoju na obszarach wiejskich,

- inwestowanie w infrastrukturę rekreacyjną, system informacji turystycznej i małą infrastrukturę turystyczną,

- utrzymanie, odbudowę i poprawę stanu dziedzictwa kulturowego i naturalnego wsi, krajobrazu wiejskiego oraz miejsc o wysokiej wartości przyrodniczej, a także działań służących podnoszeniu świadomości ekologicznej,

- współpracę z udziałem co najmniej dwóch podmiotów w zakresie opracowywania lub wprowadzania do obrotu usług turystycznych związanych z turystyką wiejską.

W ramach ostatniego z wymienionych funduszy, czyli Europejskiego Funduszu Morskiego i Rybackiego (EFMR), wspierane są m.in. badania, konferencje, wymiana najlepszych praktyk i kampanie promocyjne.

Sektor turystyczny może korzystać również z programów: LIFE, HORYZONT 2020, COSME, KREATYWNA EUROPA, ERASMUS+, Europejskiego Programu na rzecz Zatrudniania i Innowacji Społecznych.

Najczęściej projekty turystyczne finansowane z różnych funduszy i programów unijnych dotyczą:

1. infrastruktury typowo turystycznej, np. hoteli, pensjonatów, centrów konferencyjnych, przystani, wyciągów itp.,

2. infrastruktury związanej z sektorem turystycznym, np. w zakresie transportu, komunikacji, ochrony środowiska,

3. infrastruktury związanej z kulturą i dziedzictwem historycznym regionów (Meyer, Gardzińska, Sawińska, 2013).

Jak wynika z powyższej analizy, sektor turystyki może być finansowany z bardzo różnorodnych źródeł UE w zależności od specyfiki projektów. Należy jednak zauważyć, że w pozyskiwaniu środków unijnych identyfikuje się wiele barier: od barier makroekonomicznych, przez bariery finansowe, technologiczne i infrastrukturalne, prawne, informacyjne, organizacyjne, po bariery personalne i społeczne (Ren, 2013). Dodatkowo starania o wsparcie finansowe w zakresie turystyki utrudnia jej intersektorowy charakter i brak jednolitego instrumentu finansującego przedsięwzięcia turystyczne.

Projekty unijne w województwie małopolskim na tle Polski w latach 2007-2013

Powszechnie wiadomo, że środki UE odgrywają bardzo dużą rolę w rozwoju społeczno-gospodarczym Polski, a wszelkiego rodzaju inwestycje na poziomie lokalnym, regionalnym i krajowym dokonują się dzięki wsparciu z Unii (Bojar, 2006; Brambert, Kiniorska, 2019; Jaki, Rojek, 2018). Jaką rolę w poszczególnych kategoriach projektów współfinansowanych z funduszy UE odgrywają przedsięwzięcia turystyczne oraz jakie jest znaczenie tych funduszy w województwie małopolskim? 
Polska ma wyjątkowe i zróżnicowane walory przyrodnicze i uzdrowiskowe oraz bogate dziedzictwo kulturowo-historyczne, co stanowi podstawę dla rozwojowi turystyki, zarówno krajowej, jak i międzynarodowej. Województwo małopolskie zasługuje na szczególną uwagę na tle kraju ze względu na bardzo zróżnicowany krajobraz, bogate zasoby wód mineralnych i związane z nimi uzdrowiska oraz niezwykle cenne zabytki - aż osiem małopolskich zespołów i obiektów zabytkowych znajduje się na Liście światowego dziedzictwa UNESCO. Szczególną rolę w rozwoju turystyki województwa małopolskiego odgrywają miasto Kraków oraz liczne parki narodowe i krajobrazowe.

Jak wspomniano, w podnoszeniu pozycji konkurencyjnej Polski i poszczególnych układów regionalnych oraz lokalnych szczególne znaczenie mają fundusze unijne. W latach 2007-2013 podmioty turystyczne w Polsce miały możliwość uzyskania wsparcia z programów operacyjnych w kwocie 1,3 mld euro, z czego 738,47 mld euro w ramach regionalnych programów operacyjnych (RPO), co stanowiło prawie 4,5\% środków dostępnych na realizację programów regionalnych ${ }^{1}$. Należy podkreślić, że było to pięciokrotnie więcej niż w poprzednim okresie programowania. Poza regionalnymi programami operacyjnymi turystyka w szczególności korzystała ze wsparcia Programu Innowacyjna Gospodarka, Rozwój Polski Wschodniej oraz Kapitał Ludzki. W ramach RPO wspierane były projekty z pięciu kategorii: działania z zakresu turystyki wspomagające społeczno-ekonomiczny rozwój regionów, promocja działalności i aktywności turystycznej, turystyka kulturowa, ochrona przyrody oraz rewitalizacja obszarów zdegradowanych.

W latach 2007-2013 zrealizowano w Polsce 106,4 tys. projektów współfinansowanych przez UE (tabela $1^{2}$ ). Największe znaczenie miały projekty przeznaczone na rozwój firm, których wykonano aż 34,9 tys., co stanowiło 29,8\% ogólnej liczby projektów. Kolejne pozycje zajmowały projekty z kategorii praca i integracja społeczna oraz nauka i edukacja, które stanowiły odpowiednio 20,6\% i 19,2\%.

Łącznie te trzy kategorie projektów obejmowały 81,6 tys. projektów, tj. 69,6\% ogólnej liczby projektów. Najmniej projektów prowadzono w kategoriach: ochrona zdrowia (44), współpraca międzynarodowa (331) i bezpieczeństwo (590); łącznie stanowiły one zaledwie $0,8 \%$. W badanym okresie zrealizowano 2,2 tys. projektów z turystyki, co stanowiło 1,9\% ogólnej liczby projektów i spośród 15 wyróżnionych kategorii projektów stawiało je na dziewiątej pozycji. Należy jednak podkreślić, że projekty z zakresu turystyki występują również w innych kategoriach projektów, a szczególnie istotne znaczenie mają w zakresie zacieśniania współpracy międzynarodowej. Wyrazem tego jest fakt, że aż 51 projektów z kategorii współpraca międzynarodowa miało charakter turystyczny - stanowiły one 15,4\% projektów z tej grupy. Kolejne projekty, które miały wyraźne znaczenie w grupie współpraca międzynarodowa, to projekty z kategorii ochrona środowiska oraz kultura i sztuka, ale ich udział był już znacznie mniejszy (odpowiednio 7,6\% i 5,4\%).

W tym samym czasie w województwie małopolskim zrealizowano 8,9 tys. projektów, tj. 8,4\% ogólnej liczby projektów w Polsce, z czego 5,2 tys. to projekty z EFRR, 3,6 tys. z EFS, a 163 - z FS. W województwie małopolskim, podobnie jak w całej Polsce, dominowały projekty dotyczące rozwoju firm - było ich 3,1 tys., co stanowiło 30,8\% ogólnej liczby

\footnotetext{
${ }^{1}$ Zob. https://www.funduszeeuropejskie.2007-2013.gov.pl/dzialaniapromocyjne/Documents/Turystyka.pdf

${ }^{2}$ Przypisywanie niektórych projektów do więcej niż jednej kategorii powoduje, że ogólna liczba projektów przedstawionych w tabeli 1 jest nieco wyższa od rzeczywistej ich liczby, co skutkuje tym, że wyniki badań są obarczone pewnym błędem. Przeprowadzenie precyzyjniejszych analiz nie jest możliwe na podstawie danych pochodzących z portalu Mapa Dotacji UE.
} 
projektów w tym województwie. Kolejne pozycje ze zbliżoną liczbą projektów zajmowały nauka i edukacja oraz praca i integracja społeczna, których udział wynosił odpowiednio 20,7\% i 20,4\%. Kolejność tych dwóch kategorii projektów była odmienna w porównaniu z projektami z Polski, ale ze względu na bardzo zbliżone udziały dominacja projektów z zakresu nauki i edukacji nie była szczególnie wyraźna.

Tabela 1. Projekty wspófinansowane ze środków Unii Europejskiej w latach 2007-2013

\begin{tabular}{|l|r|r|r|r|}
\hline \multirow{2}{*}{$\begin{array}{c}\text { Kategorie } \\
\text { projektów }\end{array}$} & \multicolumn{2}{|c|}{ Liczba projektów } & \multicolumn{2}{c|}{ Struktura projektów } \\
\cline { 2 - 5 } & Polska & $\begin{array}{c}\text { województwo } \\
\text { małopolskie }\end{array}$ & Polska & $\begin{array}{c}\text { województwo } \\
\text { małopolskie }\end{array}$ \\
\hline Rozwój firm & 34887 & 3093 & 29,76 & 30,83 \\
\hline Nauka i edukacja & 22563 & 2077 & 19,24 & 20,70 \\
\hline Praca i integracja społeczna & 24129 & 2050 & 20,58 & 20,43 \\
\hline Telekomunikacja i e-usługi & 9485 & 764 & 8,09 & 7,61 \\
\hline Badania, rozwój, innowacje & 8498 & 719 & 7,25 & 7,17 \\
\hline Ochrona środowiska & 3560 & 273 & 3,04 & 2,72 \\
\hline Administracja & 3098 & 257 & 2,64 & 2,56 \\
\hline Transport & 3157 & 177 & 2,69 & 1,76 \\
\hline Kultura i sztuka & 1413 & 144 & 1,21 & 1,44 \\
\hline Energetyka & 1560 & 126 & 1,33 & 1,26 \\
\hline Turystyka & 2233 & 111 & 1,90 & 1,11 \\
\hline Współpraca międzynarodowa & 331 & 90 & 0,28 & 0,90 \\
\hline Bezpieczeństwo & 590 & 78 & 0,50 & 0,78 \\
\hline Rewitalizacja & 1697 & 74 & 1,45 & 0,74 \\
\hline Ochrona zdrowia & 44 & 1 & 0,04 & 0,01 \\
\hline Ogółem & 117245 & 10034 & 100,00 & 100,00 \\
\hline
\end{tabular}

Źródło: opracowanie własne na podstawie danych pochodzących z portalu Mapa Dotacji UE (https://mapadotacji.gov.pl/projekty/)

Najmniejsze znaczenie pod względem liczby miały projekty z grup: ochrona zdrowia (tylko jeden projekt), rewitalizacja (74 projekty), bezpieczeństwo (78 projektów), które łącznie obejmowały zaledwie 1,5\% ogólnej liczby projektów w województwie małopolskim. W tym czasie zrealizowano 111 projektów z turystyki, które stanowiły 1,1\% ogólnej liczby projektów w województwie małopolskim i zaledwie 5,0\% projektów turystycznych w Polsce. Spośród 15 wyróżnionych kategorii projekty z zakresu turystyki znajdowały się dopiero na 11 pozycji w województwie małopolskim, a zatem dwie pozycje niżej niż w przypadku całego kraju.

Podobnie jak w przypadku całej Polski dominujące znaczenie projektów z turystyki zaznaczyło się w grupie współpracy międzynarodowej, na co wskazuje 10 projektów, które dodatkowo miały kategorię turystyczną i stanowiły 11,1\% ogólnej liczby projektów międzynarodowych. Należy jednak zauważyć, że udział ten był o 4,3 p.p. mniejszy niż w przypadku tego typu projektów w Polsce.

Szczególne znaczenie w tym zakresie ma program Europejska Współpraca Terytorialna (EWT), w ramach którego w województwie małopolskim w analizowanym okresie 
zrealizowano wiele projektów, z czego cztery o charakterze turystycznym (Dzielmy się doświadczeniami..., 2016). Do tej grupy należy projekt „THETRIS - rozwój tematycznego szlaku turystycznego przy zaangażowaniu społeczności lokalnej”, który miał na celu usprawnienie zarządzania i wypromowanie szlaku średniowiecznych kościołów Europy Środkowej, szczególnie na obszarach wiejskich.

Kolejny projekt to „CENTRAL MARKETS - rewitalizacja i promocja tradycyjnych placów targowych w Europie Centralnej”, którego celem było opracowanie strategii odnowy i upowszechniania informacji na temat targowisk jako ważnych miejsc koncentracji życia społeczno-gospodarczego i kulturalnego, tak aby stały się one ważną atrakcją turystyczną i promowały lokalne produkty.

Następny projekt to „ReNewTown - odnowione postsocjalistyczne miasto: konkurencyjne i atrakcyjne”. Miał on na celu rozwój miast byłego bloku wschodniego przez zmniejszenie dysproporcji między nimi a innymi miastami i poprawę jakości życia mieszańców. W jego ramach zainicjowano kompleksową rewitalizację Ośrodka Kultury im. C.K. Norwida i przygotowano ofertę kulturalną ARTzony - nowohuckiej przestrzeni kreatywnej.

Kolejny projekt to „Stary Sącz i Lewocza - karpackie miasteczka z klimatem. Nowatorski transgraniczny produkt turystyki kulturowej”. Celem tego projektu była waloryzacja dziedzictwa kulturowego przez działania edukacyjne, turystyczne i promocyjne związane z estetyką przestrzeni miejskiej oraz lepszym oznakowaniem atrakcji turystycznych i zwiększeniem dostępu do informacji turystycznej. W ramach projektu odbywały się wydarzenia kulturalne oraz został opracowany przewodnik turystyczny o tradycyjnej i interaktywnej formie.

Ostatni projekt to „Poprawa jakości infrastruktury turystycznej w rejonie Pienińskiego Parku Narodowego". W ramach tego projektu po polskiej stronie wybudowano promenadę spacerową, która ciągnie się wzdłuż Grajcarka, przez jeden z najatrakcyjniejszych przyrodniczo obszarów i jest najdłuższą promenadą spacerową w Polsce. W ramach projektu przebudowano również parking przy wjeździe na przystań końcową spływu Dunajcem, wybudowano pasaż handlowo-usługowy oraz centrum informacji turystycznej nawiązujące architekturą do tradycyjnego stylu szczawnickiego. Po stronie słowackiej przebudowano dom kultury w Leśnicy na Pienińskie Centrum Turystyki Transgranicznej, co miało wpływ na wzrost nasilenia ruchu turystycznego na tym obszarze.

Projekty programu EWT przyczyniły się do zacieśnienia sąsiedzkiej współpracy, wspólnego rozwiazywania podobnych problemów, aktywizowania społeczności lokalnych, przebudowy infrastruktury turystycznej i intensyfikacji ruchu turystycznego.

Porównując struktury projektów w Polsce i województwie małopolskim, można zauważyć, że występuje pięć kategorii projektów, których znaczenie w województwie małopolskim było nieco większe niż w przypadku całej Polski. Największa różnica w udziałach wystąpiła w kategoriach nauka i edukacja oraz rozwój firm - udziały w nich w województwie małopolskim były odpowiednio wyższe o 1,5 p.p. i 1,1 p.p. od udziałów ogólnokrajowych. Większe znaczenie w województwie małopolskim miały również projekty z kategorii współpraca międzynarodowa, bezpieczeństwo, kultura i sztuka. Natomiast udział projektów z turystyki w województwie małopolskim $(1,1 \%)$ był niższy o 0,8 p.p. od udziału ogólnokrajowego.

Wartość projektów turystycznych w województwie małopolskim była zróżnicowana i wahała się od 563,6 tys. zł przeznaczonych na modernizację pieszego szlaku turystycznego do Gorczańskiego Parku Narodowego w gminie Niedźwiedź do 55,9 mln 
zł wydatkowanych na projekt pt. „Szlaki nowej przygody w zabytkowej Kopalni Soli Wieliczka”. Kolejną pozycję pod względem wartości zajmowały projekty: „Śladem europejskiej tożsamości Krakowa - szlak turystyczny po podziemiach Rynku Głównego” (37,9 mln zł), „Przystosowanie unikalnego w skali kraju obiektu zabytkowego na cele hotelarskie - adaptacja korpusu głównego Zespołu Pałacowego Goetzów w Brzesku" (29,5 mln) oraz „Modernizacja Pijalni Głównej w Krynicy-Zdroju” (28,1 mln). Najniższą wartość miały projekty: „Renowacja zabytkowego kościoła parafialnego w Pierzchnicy” (584,1 tys. zł), „Ścieżkami przemysłu chłopskiego na Orawie - nowy produkt turystyczny w Małopolsce. Rozwój Orawskiego Parku Etnograficznego w Zubrzycy Górnej” (619,6 tys.), „Budowa markowych produktów turystycznych Małopolski - wielofunkcyjne trasy rekreacyjne na terenie gminy Krynica-Zdrój” (759,5 tys. zł).

W nawiązaniu do wspomnianego powyżej podziału projektów turystycznych można zauważyć, że w województwie małopolskim zdecydowana ich większość $(88,3 \%)$ to projekty dotyczące infrastruktury typowo turystycznej, np. hoteli, pensjonatów, centrów konferencyjnych, wyciągów, pijalni i innego typu obiektów uzdrowiskowych.

Drugą kategorię projektów dotyczących infrastruktury związanej z sektorem turystycznym, np. w zakresie transportu, komunikacji, ochrony środowiska, reprezentowało dziewięć projektów dotyczących modernizacji szlaków turystycznych, tras rowerowych, szlaku żeglugi śródlądowej czy nietypowego projektu międzynarodowego pt. „Karpackie Niebo. Rozwój produktów turystycznych związanych z astronomią na terenie polsko-słowackiego pogranicza”.

Trzecia grupa obejmująca infrastrukturę związaną z kulturą i dziedzictwem historycznym regionów reprezentowana była przez cztery projekty dotyczące renowacji lub adaptacji obiektów zabytkowych w Pierzchnicy, Hebdowie, Łąkcie Górnej i Brzesku.

Najwięcej projektów turystycznych zrealizowano w Krynicy-Zdroju oraz w Muszynie (Binda, 2016). W Krynicy-Zdroju wykonano sześć projektów o łącznej wartości 46,6 mln zł (ze środków UE pochodziło 18,5 mln zł). Projekty te związane były z rewitalizacją miasta, budową parku sportowo-rekreacyjnego w Czarnym Potoku oraz budową tras rekreacyjnych. Natomiast w Muszynie zrealizowano pięć projektów o łącznej wartości 33,2 mln zł (ze środków UE pochodziło 17,4 mln zł), w tym budowę zespołu basenów oraz Parku Zdrojowego w Uzdrowisku Muszyna. Projekty z obszaru turystyka nie były realizowane aż w 146 gminach województwa małopolskiego. Wydaje się zatem, że istnieją jeszcze bardzo duże możliwości pozyskiwania środków na projekty turystyczne, które mogłyby aktywizować społeczności lokalne, kreować nowe produkty turystyczne i uatrakcyjniać ofertę turystyczną całego regionu.

\section{Uwagi końcowe}

W świetle przeprowadzonych rozważań można stwierdzić, że choć sektor turystyczny jest bardzo istotny w gospodarkach wielu państw członkowskich UE, to przez długi czas nie miał priorytetowego znaczenia w polityce wspólnotowej i nadal brakuje instrumentów finansowych w całości zorientowanych na projekty turystyczne. Intersektorowy charakter turystyki powoduje, że wiele aktów prawa unijnego odnosi się do niej w sposób pośredni lub bezpośredni. Od 2009 r. turystyka ma własną podstawę prawną, ale nadal nie ma odrębnego budżetu ani $\mathrm{w}$ ramach bieżących wieloletnich ram finansowych na lata 2014-2020, ani w ramach ostatniego wniosku dotyczącego programowania na 2021-2027 
(Coito, Klaus, Blazer, 2020). Podkreślić jednak należy, że projekty turystyczne uzyskują wsparcie z wielu różnorodnych funduszy i programów unijnych, dzięki czemu wzrastają nakłady finansowe na sektor turystyczny. Można przyjąć, że pozyskiwanie środków na projekty turystyczne jest wyrazem przedsiębiorczości regionalnej.

W województwie małopolskim, podobnie jak w całym kraju, w latach 2007-2013 dominowały projekty z kategorii rozwój firm, nauka i edukacja oraz praca i integracja społeczna, a projekty turystyczne odgrywały znacznie mniejszą rolę w ogólnej liczbie projektów wspieranych środkami unijnymi. Wydaje się, że to dominujące projekty w największym stopniu podnoszą jakość kapitału ludzkiego, pobudzają przedsiębiorczość oraz przyspieszają rozwój i innowacyjność firm, przez co przyczyniają się do kształtowania gospodarki opartej na wiedzy. Mniejsza rola projektów turystycznych w województwie małopolskim była zatem uzasadniona, a ich poziom nie odbiegał zasadniczo od poziomu projektów w Polsce.

Pomimo niekiedy uzasadnionych krytycznych ocen funkcjonowania projektów współfinansowanych przez UE oraz ich wpływu na gospodarkę zauważa się bardzo korzystne odziaływanie projektów turystycznych na wzrost ruchu turystycznego, poprawę jakości: życia społeczeństwa, infrastruktury lokalnej i stanu środowiska przyrodniczego, a także na aktywizację gospodarczą i podniesienie pozycji konkurencyjnej układów lokalnych i regionalnych w Polsce. Wydaje się, że w kolejnych perspektywach finansowania UE znaczenie projektów $\mathrm{z}$ turystyki będzie wzrastało i projekty te będą realizowane w znacznie większej liczbie gmin województwa małopolskiego.

\section{Literatura}

\section{References}

Binda, A. (2016; 2019, 5 listopada). Małopolskie Obserwatorium Polityki Rozwoju. 12. Raport roczny Fundusze Europejskie w Małopolsce. Małopolskie Obserwatorium Rozwoju Regionalnego Departamentu Polityki Regionalnej Urzędu Marszałkowskiego Województwa Małopolskiego w Krakowie. Pozyskano z: www.obserwatorium.malopolska.pl

Brambert, P., Kiniorska, I. (2019). Znaczenie funduszy unijnych dla rozwoju przedsiębiorczości i innowacyjności regionu świętokrzyskiego. Przykład klastra Grono Targowe Kielce. Przedsiębiorczość - Edukacja [Entrepreneurship - Education], 15(2), 227-247.

Bojar, E. (2006). Doświadczenia wybranych regionów słabo rozwiniętych w wykorzystaniu bezpośrednich inwestycji zagranicznych i funduszy unijnych. Wydawnictwo Politechniki Lubelskiej, Lublin.

Borowiec, M., Dorocki, S. (2014). Rozwój Krynicy-Zdroju jako wynik przedsiębiorczych działań władz samorządowych. Przedsiębiorczość - Edukacja [Entrepreneurship - Education], 10, 267-284.

Coito, E., Klaus, B., Blazer, W. (2020). Turystyka. Dokumenty informacyjne o Unii Europejskiej - 2019. Pozyskano z: http://www.europarl.europa.eu/ftu/pdf/pl/FTU_3.4.12.pdf

Čuka, P., Dorocki, S., Rachwał, T. (2015). Development of tourism infrastructure in the regions of Central and Eastern Europe. Conference: Innovation Vision 2020: from Regional Development Sustainability to Global Economic Growth, 25, 402-417.

Dorocki, S., Brzegowy, P. (2015). Zarys działalności sportowo-turystycznej w Krynicy-Zdroju po roku 1918 i jej wpływ na kształtowanie się uzdrowiskowego klastra turystycznego W: M. Zowisło, J. Kosiewicz (red.), Sport i turystyka w zwierciadle wartości społecznych. Kraków: Akademia Wychowania Fizycznego w Krakowie, 280-288.

Dorocki, S. (2007). Stacja Narciarska „Wierchomla - lokalny ośrodek aktywizacji gospodarczej. Przedsiębiorczość - Edukacja [Entrepreneurship - Education], 3, 81-87.

Dzielmy się doświadczeniami. Europejska Współpraca Terytorialna 2007-2013 w Małopolsce. (2016; 2019, 5 listopada). Urząd Marszałkowski Województwa Małopolskiego Departament Polityki 
Regionalnej. Kraków. Pozyskano z: https://www.malopolska.pl/publikacje/rozwoj-regionalny/ dzielmy-sie-doswiadczeniami-europejska-wspolpraca-terytorialna-2007-2013-w-malopolsce

Dziennik Urzędowy Unii Europejskiej C 355/10, 20.10.2017. Nowe wyzwania $i$ strategie $w$ zakresie propagowania turystyki $w$ Europie. Rezolucja Parlamentu Europejskiego $z$ dnia 29 października 2015 r. w sprawie nowych wyzwań $i$ koncepcji $w$ zakresie promowania turystyki $w$ Europie (2014/2241(INI). Pozyskano z: https:/eur-lex.europa.eu/legal-content/PL/TXT/ $\mathrm{PDF} /$ ?uri=CELEX:52015IP0391\&from $=\mathrm{SL}$

Dziennik Urzędowy Unii Europejskiej C 355/71, 20.10.2017. Nowe wyzwania i strategie $w$ zakresie propagowania turystyki $w$ Europie. Rezolucja Parlamentu Europejskiego $z$ dnia 29 października 2015 r. w sprawie nowych wyzwań $i$ koncepcji $w$ zakresie promowania turystyki w Europie (2014/2241(INI)). Pozyskano z: https:/eur-lex.europa.eu/legal-content/PL/TXT/ $\mathrm{PDF} /$ ?uri=CELEX:52015IP0391\&from $=\mathrm{SL}$

Dziennik Urzędowy Unii Europejskiej C 355/74, 20.10.2017. Nowe wyzwania i strategie w zakresie propagowania turystyki w Europie. Rezolucja Parlamentu Europejskiego z dnia 29 października 2015 r. w sprawie nowych wyzwań i koncepcji w zakresie promowania turystyki w Europie (2014/2241(INI)). Pozyskano z: https://eur-lex.europa.eu/legal-content/PL/TXT/PDF/?uri=OJ:C:2017:355:FULL\&fr om=IT

Fundusze unijne wspierają rozwój turystyki w latach 2007-2013. (2019, 5 listopada). Pozyskano z: https:// www.funduszeeuropejskie.2007-2013.gov.pl/dzialaniapromocyjne/Documents/Turystyka.pdf

Gorzelak, G. (2014). Polityka spójności a rozwój - pierwsze oceny. W: A. Kukliński, J. Woźniak (red.), Przyszłość wolności. Wymiar krajowy - regionalny - międzynarodowy. Kraków: Urząd Marszałkowski Województwa Małopolskiego, Departament Polityki Regionalnej, 317-334.

Jaki, A., Rojek, T. (2018). Rola funduszy europejskich w kreowaniu rozwoju i innowacyjności regionów w Polsce. Studia i Prace WNEIZ US, 52(2), 53-70.

Jaroszewska-Brudnicka, R. (2013). Fundusze unijne wsparciem dla rozwoju funkcji turystycznej w Bydgosko-Toruńskim Obszarze Metropolitalnym. Ekonomiczne Problemy Turystyki, 2(22), 93-109.

Meyer, B., Gardzińska, A., Sawińska, A. (2013). Znaczenie środków unijnych dla wspierania zrównoważonego rozwoju turystyki w wybranych gminach uzdrowiskowych województwa zachodniopomorskiego. Ekonomiczne Problemy Turystyki, 2(22), 155-173.

Panasiuk, A. (red.). (2014). Fundusze Unii Europejskiej w gospodarce turystycznej. Warszawa: Difin.

Portal Mapa Dotacji. (2019, 5 listopada). Pozyskano z: https://mapadotacji.gov.pl/

Program rozwoju turystyki do 2020 roku. (2019, 5 listopada). Pozyskano z: https://bip.msit.gov.pl/bip/ projekty-aktow-prawnyc/zakonczony-proces-legi/inne/1599,Program-Rozwoju-Turystyki-do-2020-roku.html

Przewodnik po funduszach UE dla sektora turystycznego 2014-2020. (2016; 2019, 5 listopada). Pozyskano z: https://op.europa.eu/pl/web/general-publications/eu-funding

Ren, S. (2013). Bariery w realizacji projektów finansowanych ze środków unijnych w ramach Programów Europejskiej Współpracy Terytorialnej na pograniczu polsko-niemieckim. Ekonomiczne Problemy Turystyki, 2(22), 111-128.

Rettinger, R. (2010). Turystyka jako czynnik aktywizacji gospodarki Chorwacji. Przedsiębiorczość Edukacja [Entrepreneurship - Education], 6, 450-461.

Siwa, I. (2006). Turystyka jako forma aktywizacji gospodarczej w regionie: aspekt zarzadzania. Warszawa: Promotor.

Sysiak, Z. (2013). Środki unijne szansą dla rozwoju turystyki obszarów wiejskich województwa lubuskiego. Ekonomiczne Problemy Turystyki, 2(22), 205-220.

Zawistowska, H., Raciniewska, E., Macierzyńska, E. (2009). Turystyka w strukturach Unii Europejskiej. Programy Unii Europejskiej dotyczace rozwoju turystyki. Przyszłość turystyki w Unii Europejskiej. Warszawa: Ministerstwo Sportu i Turystyki, Departament Turystyki. Pozyskano z: http://www. partnerstwo-zrot.pl/images/pliki/dokumenty_prawne/P5.pdf 
Zdon-Korzeniowska, M. (2009). Jak kształtować regionalne produkty turystyczne? Teoria i praktyka. Kraków: Wydawnictwo Uniwersytetu Jagiellońskiego.

Zioło, Z. (2015). Przedsiębiorczość jako czynnik rozwoju społeczno-gospodarczego układów przestrzennych. Przedsiębiorczość - Edukacja [Entrepreneurship - Education], 11, 8-23.

Zontek, Z. (2013). Finansowanie innowacji w turystyce ze środków unijnych. Ekonomiczne Problemy Turystyki, 2(22), 239-254.

Monika Borowiec-Gabryś, dr nauk o Ziemi w zakresie geografii, adiunkt w Instytucie Geografii Uniwersytetu Pedagogicznego im. Komisji Edukacji Narodowej w Krakowie. Jej zainteresowania badawcze koncentrują się wokół problematyki gospodarki opartej na wiedzy, roli szkolnictwa wyższego i ośrodków naukowych w procesie kształtowania społeczeństwa informacyjnego, procesów transformacji społeczno-gospodarczej, ze szczególnym uwzględnieniem procesów globalizacji i integracji europejskiej, a także problematyki przedsiębiorczości.

Monika Borowiec-Gabryś, PhD in Geography, associate professor at the Pedagogical University of Krakow, Institute of Geography. Her interests are concentrated on knowledge-based economy, the role of higher education and academic centres in the process of development of information society and socio-economic transformation, with particular emphasis on the processes of globalisation, European integration and entrepreneurship issues.

ORCID: https://orcid.org/0000-0001-6234-7606

\section{Adres/Address:}

Uniwersytet Pedagogiczny im. Komisji Edukacji Narodowej w Krakowie Instytut Geografii

Zakład Przedsiębiorczości i Gospodarki Przestrzennej

ul. Podchorążych 2

30-084 Krąków, Poland

e-mail: monika.borowiec-gabrys@up.krakow.pl 